\title{
KOHESI DAN KOHERENSI DALAM WACANA KOMIK BAHASA INDONESIA
}

\author{
I Gusti Ngurah Mayun Susandhika
}

\author{
Jurusan Ilmu Administrasi Negara \\ Fakultas Ilmu Sosial dan Ilmu Politik Universitas Mahendradatta \\ J1. Ken Arok No. 12, Peguyangan Denasar \\ E-mail: ngurah_yun@yahoo.co.id
}

\begin{abstract}
The marker of substitutional cohension can be found in three types: nominal, verbal, and clausal substitutional cohesion. The nominal substitutional cohension has two subtypes: personal and non-personal of nominal substitutional cohension. Meanwhile, the marker of ellipsis cohension differentiated into three types: nominal, verbal, and chaulsal ellipsis cohesion. The conjunctive cohension is differentiated into five type marke: additive, adversative, temporal, continuative, and causal. The lexical cohension is differentiated into four types: reiterative, synonimy, hyponimy, and colocative lexical cohension.

While in the coherence of comic discourse shows the existence of two systems of the forming coherence, namely coherence based on the cohesion systems, and the coherence based on the situational aspects. The coherence based on the cohension system can be differentiated into four types: equal, pposite, successive, situational aspects has two types, namely continuity step of situational coherence, and the explanation situasional coherence.
\end{abstract}

Keywords : cohesion, coherence, comic discourse.

\section{PENDAHULUAN}

Komik merupakan cerita bergambar yang disertai teks. Wacana komik terbentuk oleh perpaduan antara teks dengan gambar-gambar komik. Teks dalam wacana komik terdiri dari dialog-dialog maupun poliglot antar tokoh cerita dan deskripsi konteks pertuturan, sedangkan gambar-gambarnya merupakan pelukisan situasional cerita. Sebagai bentuk pemakaian bahasa tulis, wacana komik dapat dikatakan hemat dalam penggunaan kata-kata, karena adanya dukungan gambar-gambar komik sebagai konteks situasionalnya. Bahkan sering terdapat teks dalam wacana komik yang tidak selesai tetap dapat dipahami maksudnya setelah dihubungkan dengan gambar-gambar yang menyertainya. Adanya fenomena yang demikian itu menjadikan wacana komik sangat tepat dikaji dalam analisis wacana.

Widdowson dalam Explorations is Applied Linguistics (1985: 116) menga- takan bahwa "discourse consists of utterance with which sentences can be put into correspondence, and these combine in complex ways to relate to extralinguistic reality to achieve a communicative effect". Artinya, bahwa wacana (discourse) terdiri dari tuturan-tuturan yang berupa kalimat-kalimat yang saling berkaitan, dan berhubungan dengan faktor-faktor luar bahasa, atau kenyataan-kenyataan luar kebahasaan, sehingga kalimat-kalimat yang ada dalam wacana itu membentuk satu kesatuan yang bersifat komunikatif. Hal yang demikian itu terkandung dalam wacana komik. Pemahaman terhadap wacana komik tidak dapat dilakukan hanya dengan memahami hubugan kalimat-kalimatnya, tetapi juga harus mempertimbangkan gambar-gambar yang mendukungnya, sebagai konteks situasinya (a context of situation). Dalam hal ini konteks situasi diartikan sebagai yaitu lingkungan langsung tempat teks berfungsi (Lyons, 1983: 217; Halli- 
day dan Hasan, 1992: 62). Di samping itu, Lyons (1983: 25) mengatakan bahwa “.... utterance, like text, is to be interpreted as coverin stretches of either writer or spoken language or both, according to context", bahwa suatu tuturan, seperti halnya teks, haruslah ditafsirkan untuk membuka suatu makna dalam pemakaian bahasa tulis dan bahasa lisan, atau keduanya, dengan mempertimbangkan konteksnya. Dalam menafsirkan maksud suatu wacana, kalimat-kalimat tidak dianalisis secara isolatif, terlepas dari kalimat lain dan konteknya, melainkan harus dipandang sebagai suatu rangkaian yang saling berkaitan. Kalimat, sebagai satuan terkecil dalam wacana, mendukung satuan makna, maka hubungan antar kalimat dalam wacana tersebut menggambarkan hubungan antar makna. Hal ini berarti analisis wacana ditujukan untuk membuka suatu keberuntunan pola pikir, atau hubungan antar makna yang terkandung dalam wacana itu. Adanya keterkaitan pola pikir dan kelogisan hubungan antar makna dalam wacana disebut koherensi. Hubungan dan keserasian bentuk pada kalimat-kalimat yang terdapat dalam wacana disebut kohesi (dalam Ramlan, 1993: 10).

Koherensi merupakan kepaduan informasi atau kepaduan di bidang makna dalam suatu teks. Suatu teks pada umumnya terbentuk dari beberapa kalimat, dan kalimat-kalimat itu mempunyai kesinambungan pengertian (continuity of senses). Kesinambungan pengertian itulah yang mendasari terbentuknya koherensi suatu teks. Sehubungan dengan hal ini, Beaugrande (1981: 84) mengatakan bahwa ".... continuity of senses as the foundation of coherence, being the mutual acces and relevance within a configuration of concepts and relations", atau pengertian-pengertian yang berkesinambungan itu, sebagai dasar terbentuknya koherensi, sama-sama saling membutuhkan dan saling berkesesuaian dalam suatu konfigurasi konsep dan relasi. Kohesi dan koherensi dalam wacana merupakan aspek yang sangat penting dalam memahami maksud wacana. Dengan adanya kedua aspek tersebut, suatu wacana menampakkan adanya kesinambungan pengertian di antara elemen-elemen pembentuk wacana tersebut. Selanjutnya, pemahaman terhadap koherensi suatu wacana merupakan hal yang sangat penting dan mendasar di dalam analisis wacana, sebagaimana yang dijelaskan oleh Labov (dalam Giglioli, 1972: 299) bahwa "The foundamental problem of discourse analysis is to show how one utterance follows another in a rational, rulegoverned manner in other words, how we understand coherent discourse", yaitu bahwa permasalahan pokok dalam analisis wacana adalah bagaimana mengungkapkan hubungan-hubungan yang rasional dan kaidah-kaidah mengenai cara tersusunnya tuturan-tuturan yang beruntun.

Di dalam wacana komik, antara teks dan gambar-gambarnya saling bergantungan dan saling mendukung dalam membentuk satu kesatuan pengertian. Dengan kata lain, pemahaman terhadap wacana komik perlu mempertimbangkan hubungan antara teks dan gambar-gambarnya. Hal ini berarti wacana komik menunjukkan adanya sistem penandaan kohesi dan koherensi tertentu. Sehubungan dengan hal itu, penelitian ini ditujukan untuk mendeskripsikan sistem penandaan kohesi dan terbentuknya koherensi yang terdapat di dalam wacana komik. Penelitian ini menggunakan data-data yang berupa wacana komik, dilandasi pengertian bahwa fenomena kebahasaan yang terdapat dalam wacana komik, dapat dikatakan tidak pernah tersentuh dalam penelitian bahasa. Bertolak dari hal tersebut dapat dirumuskan beberapa permasalahan sebagai berikut:

(1) Bagaimana tipe-tipe penanda kohesi dalam wacana komik?

(2) Bagaimana terbentuknya koherensi wacana komik?

(3) Bagaimana tipe-tipe koherensi wacana komik itu berdasarkan cara terbentuknya?

(4) Aspek-aspek apa yang ikut berperan dalam terbentuknya koherensi di dalam wacana komik?

Beberapa waktu lalu, analisis bahasa dilakukan oleh ahli bahasa terhadap kalimat-kalimat, yang dianggap sebagai suatu lingual maksimal. Kalimat dianalisis sebagai satuan lingual yang mandiri dan terlepas dari konteksnya. Kalimat, sebagai suatu hasil pertuturan, tidak ditinjau dalam kerangka konteks tertentu, melainkan hanya didasarkan pada makna satuan-satuan lingual yang menjadi unsur-unsur pembentuk kalimat.

Dengan dikembangkannya studi wacana, diperoleh bukti bahwa maksud kali- 
mat yang dituturkan seseorang tidak selalu sesuai dengan makna satuan-satuan lingual dalam membentuk kalimat. Maksud suatu kalimat sering kali dapat dipahami dengan benar apabila dipertautkan dengan konteks dituturkannya kalimat tersebut. Dalam pengertian ini, dimungkinkan kalimat yang sama apabila dituturkan dalam konteks berbeda akan mengungkapkan maksud yang berbeda.

Dalam analisis wacana, kajian kalimat tidak terlepas dari konteksnya, melainkan dipertautkan dengan kalimat-kalimat lain dalam suatu pertuturan, dan faktor-faktor bersifat nonlingual, terlibat dalam proses pertuturan tersebut untuk mengungkap maksud yang terkandung dalam kalimat. Melalui analisis wacana, hakikat fungsi komunikatif bahasa dapat diungkap secara memadai. Dengan demikian, analisis wacana lebih bersifat semantis dan pragmatis. Dengan dipandangnya wacana sebagai objek kajian linguistik yang lebih memadai untuk mengungkap fungsi hakiki bahasa, maka berkembangnya teori-tori analisis bahasa dalam memasukkan konteks sebagai dasar analisis. Beberapa teori itu antara lain: teori Firtian, teori Tagmemik, teori Linguistik Teks, teori Sistemik.

\section{Teori Firthian}

Teori Firthian dilandasi oleh konsep J.R. Firth, seorang linguis London, yang beranggapan bahwa objek yang dikaji di dalam linguistik adalah pemakaian bahasa secara aktual, karena dalam di dalam pemakaian bahasa, tuturan semakin dalam hubungan antar anggota masyarakat. Di dalam pemakaian bahasa itu terdapat keterhubungan antara linguistik dan nonlinguistik. Menurutnya, dalam analisis bahasa, makna harus ditentukan berdasarkan konteksnya. Suatu kalimat tidak akan jelas maksudnya jika dianalisis di luar teks dan konteksnya (Davis, 1973; Sampson, 1980). Teori Firthian memandang bahwa sistem dan struktur bahasa dikaji dalam berbagai tataran analisis dalam konteks situasinya untuk mengungkap makna. Analisis bahasa dengan mempertimbangkan konteks situasi menuntut kerja analisis dapat memperhatikan hubungan-hubungan dalam teks itu sendiri, dan hubungan dengan konteks situasinya.

Hubungan-hubungan dalam teks itu meliputi: (a) hubungan sintagmatik an- tara unsur struktur yang dipertimbangkan dalam berbagai tataran analisis, dan (b) hubungan paradigmatik istilah atau satuan yang mengubah sistem untuk memberikan nilai pada unsur struktur. Adapun hubungan dalam konteks situasi itu meliputi: (a) hubungan teks dengan unsur nonverbal, (b) hubungan analitis antara serpihan teks dan unsur khusus dalam situasi (Samsuri, 1988).

\section{Teori Tagmemik}

Pike (1992), dengan teori Tagmemiknya mengatakan bahwa bahasa harus dipandang sebagai tingkah laku berpola dalam konteks yang berpola. Bahasa harus dipandang dalam konteks yang lebih luas. Tingkah laku verbal tidak dapat dikaji dengan memadai tanpa mempertimbangkan tingkah laku nonverbal. Pemerian bahasa harus mempertimbangkan bahwa manusia sebagai pemakai bahasa mempengaruhi hakikat satuan-satuan bahasa yang dipakainya dalam komunikasi. Oleh karena itu, reaksinya terhadap bahasa menjadi bagian data yang harus dipelajari dalam studi bahasa, karena kegunaan yang dilukiskan mengenai reaksinya itu merupakan bagian struktur bahasa. Dengan demikian, pemerian bahasa tidak hanya terbatas pada tataran fonem sebagai tataran terendah dan tataran kalimat sebagai tataran tertinggi, tetapi juga mencakup konteks tingkah laku yang lebih luas (Samsuri, 1988). Hal ini mengisyaratkan bahwa dalam mengkaji bahasa perlu mempertimbangkan hal-hal yang di luar satuan-satuan lingual, di samping mempertimbangkan hubungan-hubungan antar satuan lingual tersebut.

Menurut Teori Tagmemik, sebuah satuan dapat dipahami dengan baik hanya jika seseorang mengetahui terdapat satuan yang ditemukan. Demikian pada wacana, seluruh wacana tidak hanya ditentukan oleh kata-kata saja, tetapi lebih ditentukan oleh hubungan kata dengan budaya yang lebih luas, yaitu tempat kata-kata yang digunakan. Oleh karena itu dalam pemerian wacana, peneliti dapat menghubungkan kata-kata itu, yang dalam hal ini merupakan teks, dengan konteks situasi tempat teks tersebut berfungsi, sehingga interprestasi terhadap informasinya dapat dilakukan dengan ketepatan. Pemerian demikian itu perlu dilakukan, karena fungsi tekstual bukan saja berhubungan dengan 
kohesi gramatikal, tetapi juga dengan koherensi retorikal (Parera, 1990).

Teori Tagmemik mengungkapkan bahwa konteks situasi relevan dengan gabungan bentuk makna, dengan perubahan-perubahan, dan seluruh wacana yang ada (Pike, 1992). Seluruh wacana tidak ditentukan dengan kata-kata itu sendiri yang terdapat dalam wacana, melainkan terdapat hubungan kata-kata dengan budaya yang lebih luas, tempat kata-kata tersebut digunakan. Oleh karena itu, seluruh wacana linguistik ahli bahasa menghubungkan bahasa dengan masyarakat yang menggunakannya. Wacana itu sendiri, menurut teori Tagmemik dapat dikatakan sebagai suatu bentuk Tagmem, yaitu satuan dalam konteks. Dalam analisis tagmen itu diperlukan adanya keutuhan antara fungsi, bentuk, peran, dan kohesi. Itulah sebabnya, dalam analisis bahasa, hal ini dapat dikhususkan masalah wacana, teori Tagmemik sangat mempertimbangkan pentingnya konteks situasinya, yaitu menjangkau makna diungkapkan penutur dengan bahasanya.

\section{Teori Linguistik Teks}

Beugrande dalam Introduction to Text Linguistic (1981) menjelaskan bahwa teks merupakan suatu peristiwa komunikasi (communication accurrence). Aspek koherensi sebagai salah satu standar kualitas suatu wacana atau standard textualy suatu wacana, di samping aspek kohesi, intensionalitas dalam akseptabilitas, informatif, situasionalitas, dan intertekstualitas. Menurutnya, koherensi dalam suatu wacana tercipta karena adanya kesinambungan pengertian.

Teori Linguistik Teks berpandangan bahwa suatu ekspresi bahasa (a language expression) merupakan bentuk menghadirkan dan penyampaian pengetahuan. Pengertian ekspresi bahasa pada hakikatnya merupakan pengetahuan-pengetahuan yang disampaikan melalui bahasa dalam bentuk teks. Dengan demikian, tidak berarti bahwa pengetahuan identik dengan ekspresi bahasa, karena pengertian yang berkandung dalam suatu ekspresi bahasa pada dasarnya merupakan konfigurasi antara konsep-konsep dan hubugan-hubungan dengan pengetahuan tentang dunia. Koherensi suatu wacana didasarkan atas adanya kesinambungan pengertian di da- lam wacana tersebut, maka dalam mengidentifikasi koherensi wacana juga harus mengetahui hal-hal yang membentuk kesinambungan pengertian dalam suatu wacana. Menurut Beaugrande hal-hal yang perlu dipertimbangkan dalam menemukan kesinambungan pengertian itu adalah konsep-konsep yang teraktifkan (activated concepts) dalam ekspresi bahasa.

Konsep-konsep itu pada dasarnya merupakan konfigurasi antara pengetahuan-pengetahuan tentang dunia yang dapat dimunculkan kembali atau dapat diaktifkan. Konsep-konsep itu dapat dikelompokkan ke dalam dua kelompok, yaitu konsep primer (primary concept) dan konsep sekunder (secondary concept). Konsep primer meliputi: (a) Objek (Object), yaitu entitas-entitas konseptual dengan identitas dan konstitusi yang stabil. (b) Situasi (Situations), yaitu konfigurasi antara objek-objek yang saling menghadirkan dalam keadaan tertentu. (c) Peristiwa (event), yaitu kejadian-kejadian yang dapat mengubah situasi atau keadaan dalam suatu situasi. (d) Tindakan (actions), yaitu peristiwa-peristiwa yang dialami oleh para pelaku. Adapun konsep sekunder meliputi: keadaan, pelaku, entitas yang berpengaruh, relasi, atribut, lokasi, waktu, gerakan, alat, bentuk, bagian, substansi, isi, sebab, kemungkinan, alasan, tujuan, apersepsi, kognisi, emosi, kemauan, pengakuan, komunikasi, pemilikan, kejadian, kuantitas, keperluan, signifikansi, nilai, ekuivalensi, pertentangan, koreferensi, dan rekurensi. Tipe-tipe konsep tersebut digunakan untuk mengklasifikasikan hubungan-hubungan kebahasaan berdasarkan pengorganisasian peristiwa-peristiwa dan situasinya.

\section{Teori Sistemik}

Teori Sistemik merupakan teori linguistik yang dikembangkan oleh Halliday (Sampson, 1980). Teori ini pada dasarnya merupakan pengembangan dari konsep-konsep linguistik yang dikemukakan oleh Firth. Menurut Halliday, yang menekankan kajian bahasanya berdasarkan konteks sosial, jalan menurut pemahaman terhadap bahasa terletak dalam kajian teks (Halliday dan Hasan, 1992). Dapat dikatakan bahwa kajian semacam itu akan atau ditemukan adanya teks, dan ada teks lain yang menyertainya. Teks yang menyertai teks itu merupakan konteks. Di dalam teks 
itu ada sesuatu yang mengikat kalimat-kalimat itu menjadi sebuah teks, menyebabkan pendengar atau pembaca mengetahui bahwa dengan berhadapan dengan teks atau wacana, bukan suatu kumpulan kalimat tanpa ikatan.

Tali pengikat itu dinamakan tekstur (Hasan Lubis, 1993). Adapun konteks dalam pengertian ini tidak hanya menyangkut apa yang dilisankan atau dituliskan, melainkan termasuk juga kejadian-kejadian yang nonverbal, yaitu menyangkut keseluruhan lingkungan teks itu.

Dalam kaitannya dengan masalah koherensi wacana, Halliday dan Hasan (1993) menjelaskan bahwa sumbangan yang penting bagi koherensi suatu teks berasal dari kohesi, (bandingkan juga Beaugrande, 1981: 71). Dikatakannya bahwa kohesi merupakan perangkat sumber-sumber kebahasan yang dimiliki oleh setiap bahasa sebagai bagian dari metafungsi tekstual untuk mengaitkan satu bagian teks dengan bagian lainnya. Dalam bukunya Cohesion in English, Halliday dan Hasan menjelaskan adanya lima macam tipe kohesi dalam bahasa Inggris, yaitu:

1) Reference, yaitu pengacuan terhadap unsur-unsur yang mendahuluinya atau yang mengikutinya yang mempunyai hubungan makna. Pengacuan terhadap unsur-unsur yang mendahului, atau unsur-unsur yang telah disebutkan sebelumnya dalam teks disebut pengacuan anaforis, sedangkan pengacuan terhadap unsur-unsur yang mengikuti atau pengacuan terhadap unsur-unsur yang akan disebutkan kemudian dinamakan pengacuan kataforis. Mereka memberikan contoh teks yang mengandung penanda kohesi referensial sebagai berikut:

(a) Doctor foster went to Gloucester in a shower of rain. He stepped in a puddle right up to his middle and never went there again.

Dalam teks tersebut unsur there pada kalimat kedua mengacu secara anaforis pada unsur Gloucester pada kalimat pertama.

2) Substitution, yaitu penggantian kata, kelompok kata atau unsur kalimat dengan kata yang lain. Contohnya:

(b) My axe is too blunt. I must get a sharper one.
Unsur one dalam kalimat kedua dalam teks tersebut menggantikan unsur axe pada kalimat sebelumnya.

3) Ellipsis, yaitu kohesi yang berupa penghilangan suatu kata atau bagian dari kalimat dalam suatu teks. Penghilangan ini dilakukan terhadap kata atau bagian kalimat yang sama digunakan pada kalimat lain dalam teks, untuk menghindari penyebutan yang berulang, sehingga makna dari unsur yang dihilangkan itu masih dapat dimengerti. Kohesi elipsis ini dapat juga disebut sebagai substitution by zero. Sebagai contoh, misalnya: (c) "And how many hours a day did you do lessons?" said Alice, in a hurry to change the subject. "Ten hours the first day," said the Mock Turtle, "nine the next, and so on."

Unsur nine pada tuturan kedua dalam teks tersebut yang dimaksudkan adalah nine hours yang mengalami pelepasan unsur. Demikian juga, unsur the next pada tuturan kedua itu yang dimaksudkan adalah the next day yang mengalami pelepasan unsur.

4) Conjuction, yaitu kohesi yang berupa bentuk-bentuk penanda hubungan yang menandai adanya keterkaitan antara kalimat yang satu dengan kalimat lain dalam teks. Penanda hubungan yang sering muncul dalam bahasa Inggris adalah hubungan penambahan, hubungan sebab, dan hubungan waktu. Hubungan ini dapat bersifat hipotaksis, yaitu hubungan antara klausa utama dengan klausa bawahan, dapat dikaitkan hubungan yang bersifat parataksis, yaitu hubungan antara dua klausa yang setara. Misalnya:

(d) She was never really happy here. So she's leaving.

Unsur so pada kalimat kedua dalam teks tersebut merupakan penanda kohesi konjungsi yang menunjukkan adanya hubungan sebab antara kalimat kedua itu dengan kalimat pertama.

5) Lexical Cohesion, yaitu kohesi yang didasarkan atas adanya pemakaian kata-kata yang mempunyai relasi semantik. Tipe kohesi leksikal dalam bahasa Inggris antara lain yaitu pengulangan (reiteration) dan kolokasi (collocation). Jadi, kohesi leksikal ini tidak didasarkan atas adanya hubungan gramatikal 
bentuk-bentuk yang digunakan dalam teks. Misalnya:

(e) Henry's bought himsift a new Jaguar. He practically lives in the car.

Unsur the car pada kalimat kedua teks tersebut merupakan pengacuan leksikal yang mengulang unsur Jaguar pada kalimat pertama.

\section{Metode Penelitian}

Sesuai dengan tahapan-tahapan dan prosedur penelitian yang ditempuh dalam penulisan artikel ini, maka metodologi penelitian ini yang dijabarkan dalam tulisan ini berdasarkan tahapan strateginya meliputi metode dan teknik pengumpulan data, metode dan teknik analisis data, dan metode pemaparan hasil analisis data, atau metode penyajian hasil penguraian data (Sudaryanto, 1992: 57).

Data yang dianalisis dalam penelitian ini berupa penggalan-penggalan teks yang diambil dari komik-komik berbahasa Indonesia, yang diterbitkan dalam bentuk buku. Oleh karena itu, pengumpulan data dalam penelitian ini dilakukan dengan mengadakan penyimakan (metode simak) terhadap komik-komik tersebut. Adapun buku-buku komik yang menjadi sumber data dalam penelitian ini:

1) Is Yuniarto, Garudayana. (Aksi)

2) Rimanti Nurdarina, Pace: The Guility. (MNC)

3) Ockto Baringbing dan Hendry Zero. Bima Satria Garuda. (Alfamart)

4) Vanslyner. Delinquent. (Makko)

5) Go King Matto. 5 Menit Sebelum Tayang. (Makko)

6) Pandji Pragiwaksono. H2O. (Kolam Komik)

7) Marcellino Lefrandt dan Aswin MC Siregar. Volt. (Skylar Comic)

8) Is Yunarto. Knight of Apocalypse. (Aksi Comic)

9) Ockto Baringbing dan Ino Septian. Galauman. (Comic)

10) Vega Mandalika. Nusantara Droid War. (Comictoon)

11) Nurfadli Mursyid. Tahilalats. (Comictoon)

12) Mas Oki dan S.M.S. Terlalu Tampan. (Comictoon).

Bersumber dari buku-buku komik itu dilakukan pencatatan terhadap bagian-bagian teks dengan mempertimbangkan spesifikasi sistem penandaan kohesi dan terbentuknya koherensi dalam teks tersebut. Klasifikasi data dilakukan dengan memilah data pada tipe-tipe penanda kohesi dan terbentuknya koherensi.

Setelah data terkumpul diklasifikasikan kemudian dianalisis menggunakan metode padan, terutama menggunakan teknik referensial, dan metode agih terutama menggunakan teknik substitusi, teknik perluas, dan teknik paraphrase. Di samping itu digunakan juga metode refleksif-introspektif (mengenai teknik-teknik analisis ini lihat Sudaryanto, 1993). Teknik substitusi digunakan untuk menganalisis teks-teks koherensinya bersumber dari hubungan kohesif, yaitu dengan menggantikan penanda kohesif dalam teks itu dapat ditunjukkan. Adapun teknik referensial digunakan untuk menganalisis teks yang koherensinya bersumber dari hubungan teks dengan konteks situasinya, sehingga keterhubungan unsur-unsur teks itu dapat ditunjukkan. Selanjutnya, untuk membuktikan koherensi teks-teks tersebut digunakan teknik paraphrase dan metode refleksif-introspektif, yaitu dengan menyusun kembali teks-teks itu dengan memasukkan unsur-unsur kontekstualnya, sehingga kepaduan makna teks itu dapat dipahami dengan jelas. Setelah tahap analisis dilaksanakan, hasil analisis data itu dipaparkan menggunakan metode penyajian secara informal, yaitu penyajian dengan menggunakan kata-kata, atau berupa uraian.

\section{Hasil Penelitian}

Secara kontekstual, wacana komik memiliki dua jenis konteks, yaitu konteks linguistik dan konteks nonlinguistik. Konteks linguistik merupakan konteks yang berupa bagian-bagian teks itu sendiri, karena bagian-bagian teks itu membentuk suatu kesatuan teks, dalam arti bagian teks yang satu menjadi konteks bagian teks yang lain. Konteks nonlinguistik merupakan konteks yang tidak berupa teks. Dalam wacana komik, konteks nonlinguistik berupa gambar-gambar komik. Berdasarkan dua jenis konteks itulah dalam penelitian ini ditentukan tipe-tipe kohesi yang terdapat dalam wacana komik.

Sistem penandaan kohesi yang terdapat dalam wacana komik ada lima macam, yaitu kohesi referensial, kohesi substitusional, kohesi elipsis, kohesi konjungtif, dan kohesi leksikal. Penanda kohesi referensial bersifat leksiko-semantis. Penanda kohesi ini dapat dibedakan menjadi tiga tipe, yaitu penanda kohesi referensial pronominal dan penanda kohesi referensial demonstratif. 
Penanda kohesi referensial pronominal terdiri dari enam subtipe, yaitu: (1) Penanda kohesi referensial pronominal yang bersifat endoforis, berupa ia, dia, dan mereka yang mengacu nama-nama orang yang disebutkan dalam teks. (2) Penanda kohesi referensial pronominal yang bersifat eksoforis, berupa kita, mereka, kalian, kau, dan aku yang digunakan untuk mengacu pelibat pertuturan yang namanya tidak disebutkan dalam teks. (3) Penanda kohesi referensial pronominal diektik, berupa aku dan kamu. Penanda kohesi ini terdapat wacana dialog dan poliglot. Dalam dialog maupun poliglot tentu terjadi pertukaran, dan dalam pertukaran itu pronominal aku dan kamu digunakan untuk mengacu pelibat pertuturan secara berganti-ganti. (4) Penanda kohesi referensial pronominal nondiektik, berupa dia dan mereka. (5) Penanda kohesi referensial pronominal posesif. Penanda kohesi ini berupa pronominal yang menyatakan hubungan kepemilikan, sehingga ada yang berbentuk klitik ku, mu, dan nya, dan ada pula yang berbentuk nonklitik kita, kalian, dan kamu. (6) Penanda kohesi referensial pronominal nonposesif, yang merupakan penggunaan pronominal yang tidak menunjukkan hubungan kepemilikan. Penanda kohesi ini secara gramatikal berfungsi sebagai subjek atau objek dalam kalimat. Bentuk penanda kohesi ini ada yang berbentuk klitik ku dan mu, ada pula yang berbentuk nonklitik aku, kamu, kau, kita, kami, dan mereka.

Penanda kohesi referensial demonstratif dibedakan menjadi tiga subtipe yaitu penanda kohesi demonstratif nominal, berupa ini, itu, dan tersebut; penanda kohesi referensial demonstratif temporal, berupa tadi; dan penanda kohesi referensial demonstratif lokatif, berupa sini, situ, dan sana.

Penanda kohesi referensial komparatif dibedakan menjadi tiga subtipe, yaitu penanda kohesi referensial komparatif similatif, berupa seperti, bagai(kan), seolah-olah, dan seakan-akan; penanda kohesi referensial elatif lebih dan paling; serta penanda kohesi referensial komparatif identik, berupa persis, sama dengan, dan afiks se- yang diikuti kata berkategori ajektif.

Penanda kohesi subtitusi bersifat leksiko-gramatikal. Penanda kohesi ini dalam wacana komik ditemukan tiga tipe penanda, yaitu penanda kohesi substitusi nominal, penanda kohesi substitusi verbal, dan penanda kohesi klausal. Penanda kohesi substi- tusi nominal dibedakan menjadi dua subtipe, yaitu penanda kohesi substitusi nominal personal, berupa beliau, kau, ia, dia, dirimu, dan mereka; dan penanda kohesi substitusi nominal nonpersonal, berupa ini, itu, begini, dan apa. Penanda kohesi subtitusi verbal berupa itu, begitu, dan demikian.

Penanda kohesi substitusi klausal berupa begitu, begini, itu, dan (hal) demikian. Penanda kohesi elipsis dibedakan menjadi tipe-tipe, yaitu penanda kohesi elipsis nominal, penanda kohesi elipsis verbal, dan penanda kohesi elipsis klausal. Penanda kohesi Konjungtif dibedakan menjadi lima tipe yaitu penanda kohesi konjungtif aditif, penanda kohesi konjungtif adversatif, penanda kohesi konjungtif temporal, penanda kohesi konjungtif kontinuatif, dan penanda kohesi konjungtif kausal. Penanda kohesi leksikal dibedakan menjadi empat tipe yaitu penanda kohesi leksikal reiteratif, penanda kohesi leksikal sinonimi, penanda kohesi leksikal hiponimi, dan penanda kohesi leksikal kolokatif.

Adapun dalam hal koherensi, wacana komik menunjukkan adanya dua sistem pembentukan koherensi, yaitu koherensi yang bersumber dari hubungan kohesi, dan koherensi yang bersumber dari aspek situasional. Koherensi yang bersumber dari hubungan kohesi dibedakan menjadi empat tipe yaitu koherensi kesamaan yang terdiri dari enam subtipe, koherensi keberlawanan, koherensi perturutan yang terdiri dari tiga subtipe, dan koherensi penjelasan yang dibedakan menjadi empat subtipe.

Koherensi yang bersumber dari aspek situasional dapat dibedakan menjadi dua tipe, yaitu koherensi situasional kesinambungan tindakan, dan koherensi situasional penjelasan, yang mempunyai tiga subtipe, yaitu koherensi situasional penjelasan keadaan, koherensi situasional penjelasan hasil, dan koherensi situasional penjelasan peristiwa.

Dalam penelitian ini peneliti memberanikan diri memberi nama untuk tipe-tipe koherensi yang ditemukan karena pada kajian-kajian wacana yang dilakukan ahli bahasa terdahulu tidak membicarakan masalah tipologi koherensi. Dalam penelitian tentang wacana, istilah-istilah baru dalam hubungan dengan tipologi masalah kohesi.

Istilah-istilah yang digunakan untuk penamaan tipe koherensi ini ditentukan berdasarkan hubungan makna yang secara dominan terbentuk dalam wacana tersebut. 
Hubungan makna antara unsur pembentukan wacana itu berasal dari keterkaitan kalimat satu dengan kalimat yang lain, dapat juga berasal dari keterkaitan antara kalimat-kalimat dalam wacana itu dengan aspek situasionalnya yang berupa gambar-gambar yang mendukung apa yang diungkapkan dalam kalimat-kalimat pembentukan wacana itu.

\section{DAFTAR PUSTAKA}

Atar Semi, 1990. Menulis Efektif. Bandung: Angkasa.

Beaugrande, Robert-Alain de. 1981. Inroduction to Text Linguistics. London: Longman.

Budi Santoso, Gunawan. 1987. "Ciri-Ciri Bahasa Komik sebagai Sebuah Ragam”. Magelang; (Makalah) PIBSI.

Crytal, David. 1991. A Dictionary of Linguistics and Phonetics. Oxford: Basil Blackwell, Ltd.

Dardjowidjojo, (et al). 1988. Tata Bahasa Baku Bahasa Indonesia. Jakarta: Balai Pustaka.

Dardjowidjojo, Sunjono. 1985. "Benang Pengikat dalam Wacana", dalam Kaswanti Purwo, 1990. Pusparagam Linguistik dan Pengajaran Bahasa. Jakarta: Arcan, h. 93 - 110.

Davis, Philip W. 1973. Modern Theories of Linguistics. London: Hutchinson.

Djajasudarma, Fatimah. 1994. Wacana: Pemahaman dan Hubungan Antar Unsur. Bandung: Eresco.

Giglioli, Pier Paulo (ed). Language and Social Context. London: Pengius Books.

Grixe H.P. 1975. "Logic and Conversation", dalam Cole P. dan Morgon J. (ed) Syntax and Semantics, Vol. 3. New York: Academy Press.

Halliday, M.A.K. dan Ruqaiya Hasan. 1979. Cohesion in English. London: Longman.

Halliday, M.A.K. 1992. Bahasa Konteks dan Teks (terjemahan Asruddin Barori Tou). Yogyakarta: Gadjah Mada University Press.

Hasan, Ruqaiya. 1968. Grammatical Cohesion in Spoken and Written and Written English. London: Longman.
Kaswanti Purwo, Bambang. 1990. Pusparagam Linguistik dan Pengajaran Bahasa. Jakarta: Arcan.

Kaswanti Purwo, Bambang. 1993. PELLBA 6. Jakarta: Lembaga Bahasa Unika Atma Jaya.

Leech, Geoffrey, N. 1983. Principles of Pragmatics. New York: Longman.

Lubis, Hamid Hasan. 1993. Analisis Wacana Pragamatik. Bandung: Angkasa.

Lyons, John. 1983. Language, Meaning, and Context. Great Britain: Fontana Paper Backs.

Parera, Jos Daniel. 1990. Teori Semantik. Jakarta: Erlangga.

Pike, Kenneth L. 1992. Konsep Linguistik: Pengantar Teori Tagmemik. Jakarta: Summer Institute of Linguistics.

Ramlan, M. 1993. Paragraf: Alur Pikiran dan Kepaduannya dalam Bahasa Indonesia. Yogyakarta: Andi Offset.

Renkema, Jan. 1993. Discourse Studies: An Introductory Text Book. Amsterdam: John Benjamins Publishing Company.

Samson, Geoffrey. 1980. School of Linguistics. London: Hutchinson.

Samsuri. 1998. Analisis Bahasa. Jakarta: Erlangga.

Sudaryanto. 1992. Metode Linguistik. Yogyakarta: Gadjah Mada University Press.

Sudaryanto. 1993. Metode dan Aneka Teknik Analisis Bahasa. Yogyakarta: Duta Wacana University Press.

Sudjatmika, Wuri. 1991. "Aspek Linguistik dan Sosiokultural dalam Humor", Makalah Pertemuan Linguistik. Jakarta: Unika Atma Jaya.

Tarigan, Henry Guntur. 1987. Pengajaran Wacana. Bandung: Angkasa.

Suwito. 1985. Sosiolinguistik: Pengantar Awal. Solo: Henary Offset.

Widdowson, H.G. 1985. Explorations in Applied Linguistics. London: Oxford University. 